\title{
低温技術講座
}

\section{Cryostat の設計法}

\author{
河喜 多 能 正 \\ 株式会社，東理社 川口市青木町 3-5-1 \\ (1976年 1 月 28 日受理) \\ Introduction to cryostat design \\ Yoshimasa KawAKITA \\ Torisha Co., LTD. \\ 3-5-1, Aoki-cho, Kawaguchi \\ (Received Jan. 28, 1976)
}

\section{Synopsis :}

Recetly, the application of low-temperature processes and techniques has become quite important not only in basic research but also in industrial technology.

The cryostat is indispensable in these studies and this paper gives an outline of recent development in metalic cryostats. Several examples are shown to explain concretely design problems and recent trends.

\section{1. まえがき}

Cryostat（以下 C.S. と略称）とは極低温における 物性, 其他の研究にあたって, 試料を任意の温度に保 つ恒温槽と定義されるが, 最近では教科書的な物性研 究に使用されるのと同じ位，実用的な低温装置への鹳 型としての利用度が多くなった様に考えられる。すな わち超電導送電, 磁気浮上, 磁石, 口ケットや自動車 の燃料装置, SQUID 等々。従って機械的な強度, 耐 久力の問題, 安定した性能, 使い易さ等への要求が更 に大となり，またその使用目的，規模もそれぞれ異な ったものが多く，ほとんど新設計によるものであるの で，特に材料の選定，極端条件下においても無理のな 、設計，製作上に㧈ける管理の徹底を期さね攼ならな い。しかしながら設計上に扔ける基本的姿勢は低温を 扱らことに本質的に変るものではないので，ここでは 基礎的な事項を主として其の要点を述べてみよう。

\section{2. 各 C.S. における共通な設計上の要点}

C.S. はあとで述べるようにその使用目的が多種多
様であり，冷却方法としても，低温液化ガス等の寒 剂, 液化機, 冷凍機を使用するが, 何れも低温の気化 し易いしかも高価なガスを使用することになるので， 設計上共通な点が多い。液体 $\mathrm{He}$ 使用の C.S. の例を 戝1 亿示す。

設計の方針とするのは, 他低温機器と同じく,

1）熱侵入が少くかつ初期冷却に要する寒剤の口ス が少い。

2) 使用に際して破壊したり,リークが起ったりし ない。

3）試料を所期の低温度に保つことが出来かつ機械 的保持が安定であること。

4) 光，他の輻射線に対する空は，光軸に対し直角 で，散乱や反射が少なく，また吸収の少ないものであ る。

5）低温収縮に対する考慮がなされていること。

6) 目的とする温度, 精度に適する温度計素子をつ ける。

等の基礎的事項があげられる他，使、易い事が大切な 事である。

低 温工学 


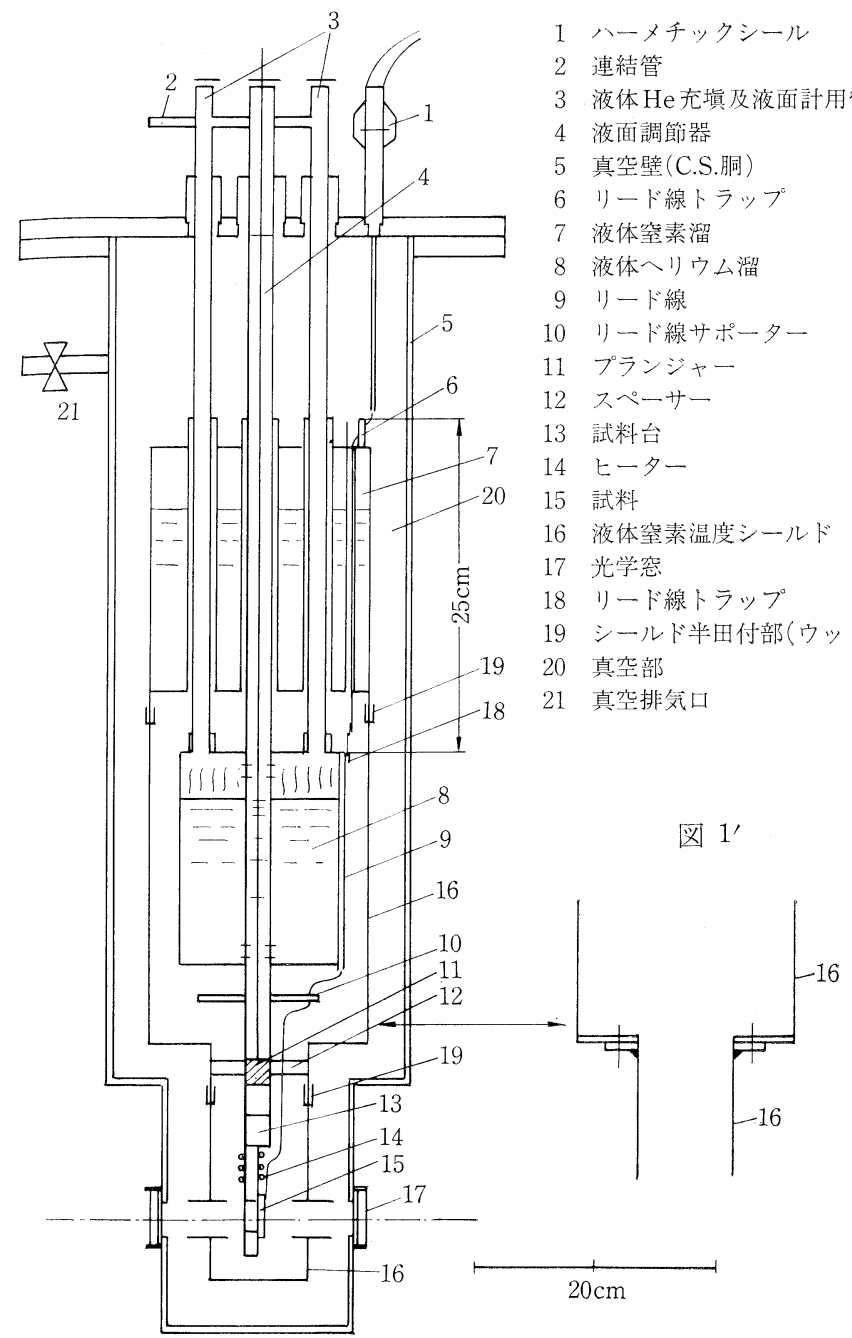

図 1

\section{1 断熱について}

熱の外部からの侵入は極力防止しなければならな い。ことに液体 $\mathrm{He}$ 温度以下の温度を得ようとするも のでは, 熱シールドを何重にも作り,侵入熱を如何に少 くすることが出来るかということが重要な鍵である。

今，図 1 について熱侵入を考えて見るに, $\mathrm{He}$ 溜及試 料部に対する固体熱伝導としては，上部のパイプ類， ヒーターリード，熱電対，下部におけるスペーサー等 があるが，周囲は全部液体 $\mathrm{N}_{2}$ 温度のシールドを施し てあり,リード線類も図のよらに液体 $\mathrm{N}_{2}$ 部分にトラ ップしてあるとすれば，各部からの流入熱量は，概略

$$
W_{c}=\frac{A}{L} \bar{k}\left(\mathrm{~T}_{2}-\mathrm{T}_{1}\right) \text { より }
$$

Vol. 11 No. 3 (1976)
$W_{c}$ : 伝導熱量 $\mathrm{W}, A$ : 固体断面 積 $\mathrm{cm}^{2}, L$ : 長さ $\mathrm{cm}$, $\bar{b}$ : 平均熱 伝導率 $\mathrm{W} / \mathrm{cm} \operatorname{deg} \mathrm{K}, T_{2}, T_{1}$ : 高温部, 低温部の絶対温度ここで は $77^{\circ} \mathrm{K}, 4.2^{\circ} \mathrm{K}$ ステンレスパイプ 3 本 $(\bar{k}=0.045 \mathrm{~W} / \mathrm{cm} \operatorname{deg} \mathrm{K} 1$ - (1) $0.053 \mathrm{~W}$, Nylon スペーサー $(\bar{k}=$ $0.0014 \mathrm{~W} / \mathrm{cm} \operatorname{deg} \mathrm{K} 1$-(2) 0.165 $\mathrm{W}$, ヒーターリード 3 本 $(\bar{k} /(\mathrm{Cu})$ $=9.8 \mathrm{~W} / \mathrm{cm} \mathrm{deg} \mathrm{K} 1-3) 0.026 \mathrm{~W}$, 熱電対 $A u(\mathrm{CO}) 1$ 本 $\bar{k}=3.5 \mathrm{~W} / \mathrm{cm}$ dag K1-(4)) $0.003 \mathrm{~W}$,

となるが此の内パイプよりの伝熱 は，パイプ上部を常温部分で互に連 結し， 3 本のパイプ全部に蒸発 $\mathrm{He}$ ガスを通すようにしてあるので，相 当量迄キャンセルすることが出来 る。問題になるのはスペーサーであ るが,この計算は Nylon 雨端にお ける接触抵抗がないとしたもので， 実際には接触点も少く経路も長い構 造とする。本例では星形として約 $0.03 \mathrm{~W}$ 位の伝熱量が考えられる。 また振動を考えなければ略すること もできる。熱伝対ヒーターリードは なる心゙く細いもの(本例では $0.2^{m} /$ ) を用い，本例では行わないが超電導 コイルのパワーリード等気化ガス中 を通せる場合には熱交換を十分行わ しめる。また直径の大きなパイプを 使用したもの, 円筒型容器では輻射 防止板を入れた断熱性盍を使用しかつ気化ガスがこの 板やパイプ壁を冷却する構造とする。これを綜合すれ ば本例での固体熱伝導による流入熱量は, 大約 0.11 Wと考えられる。

常温の真空壁面を通じての輻射熱侵入には, 高低温 の両真空壁を研摩したり emissivity の少ない金属を 鍍金するとか或は super insulation を施す。ただし 試料交換のため真空面を外気にさらしたり，しばしば 手にて触れたりする方式のC.S.にあっては, ステンレ ス製のものでは研摩，銅では手を触れる部分には金鍍 金の方がよく，銀鍍金，アルミ合金，銅研摩の場合に は更に表面に透明塗料を薄く塗ったものの方が emissixity 㔫保ちさせる研究 ${ }^{2)}$ ある。極低温部分に 
対しては液体 $\mathrm{N}_{2}$ 温度あるいは液体 $\mathrm{He}$ 温度の熱シー ルドを設ける。真空封じ切り式の C.S. ではしばしば superinsulation 方式が用いられる。これは金属簿と らすい熱絶物を交互に組合はせたもので，金属簿には アルミ管, アルミ蒸着マイラー, 熱絶縁物にはガラス 繊維等が用いられる。従って熱の伝導には輻射による 部分と，固体伝導による部分があるが，温度が高い方 では輻射の方の影響が多く，低温部分では固体伝導に よる割合が大きい事は次出の式の $Q_{E}$ が温度の 4 乗に 比例することで明らかなことであろら。従って断熱能 カとしては全体としてのスーパー材の性質, 巻き方巻 き回数等による他，低温部分と高温部分とに異った応 用の仕方を考えなければならない。

図 1 につき輻射による熱流入を考えてみると, 真空 面を通じての輻射, 上部パイプからの inflowdaun, 下部密を通じてのもの，等に分けられる。

Stefan-Boltzmann の式 $W=\sigma e A T^{4}$ $e:$ 温度 Tに颃いての全 emissivity $A:$ 面積 $\sigma: 5.67 \times 10^{-12} \mathrm{watt}_{\mathrm{cm}}^{-2}(\operatorname{deg} \mathrm{K})^{-4}$ よりその概略值としての式

$$
\frac{Q_{E}}{A_{1}}=\sigma \frac{1\left(T_{2^{4}}-T_{1^{4}}\right) \text { (3) }}{\frac{1}{e_{1}}+\frac{A_{1}}{A_{2}}\left(\frac{1}{e_{2}}-1\right)} \text { を用いて計算すれば }
$$

但し 1.2 は夫々内容器外容器を示す

液体 $\mathrm{N}_{2}$ 温度シールドより液体 $\mathrm{He}$ 溜及試料部への輻 射流入熱量はシールドを銅研摩として約 $0.009 \mathrm{~W}$ パイプ上部からの輻射 " $0.003 \mathrm{~W}$ 空から $(\phi 30 m / m 2$ ケ $) \quad " 0.186 \mathrm{~W}$ この場合光学空の通路には常温部分から輻射熱流入を 成可く少く寸るため, 光軸仁副って液体 $\mathrm{N}_{2}$ 温度のパ イプを作り中を黒くしておく。また空からの輻射流入 熱が他に比べて極端に多いため本例では使用しなかっ たがこれを防止するには可視光線を通して赤外線を通 し難、空. heat absorbing filter が使用されその大部 分を吸収できる。上記の計算を綜合すれば図 1 におけ る輻射流入熱量は略 $0.2 \mathrm{~W}$ となる。本例では試料部 分の近くの液体 $\mathrm{N}_{2}$ シールドはウッドメタル等にてロ 一付してあり部分的な温度傾度は殆んどないが，図 $1^{\prime}$ に示すようにフランジにてネジ止とすれば，その接触 状態により上部液体 $\mathrm{N}_{2}$ 温度のシールドより高い温度 になっている場合が多い。その結果としてシールド部 加の輻射は急増し, 液体 $\mathrm{He}$ の蒸発量の増加, 試料 部の温度上昇を来たす。ことに試料部が $\mathrm{He}$ 溜にネジ
止の場合は, どうしても液体 $\mathrm{He}$ 温度近くまで下がら ないといら結果が多い。ゆえに $\mathrm{N}_{2}$ シールドの温度が $100^{\circ} \mathrm{K}$ であれば輻射は 3 倍近く $120^{\circ} \mathrm{K}$ では 6 倍近く なる。

上記の例のように接触部分があるために熱シールド の温度が十分下らないとか，ヒートスイッチ等におい て接触部分の熱伝導は重要な問題である。C.S. 等に おいて熱左導をよくす心゙き場所に止むを得ず接触部を 作る場合は接触部の間にインジウム，金，銀線を入れ 強く締付ける等のことを行う。またこれは真空のシー ルにも応用できる。

残留ガスによる熱伝導はわずかであり, また液体 $\mathrm{He}$ が入れば真空度が上るのであまり問題はないが容 器にリークがあれば問題は別である。残留ガスの熱伝 導については, Knudsen の式から

$$
\begin{gathered}
W=2.467 \times 10^{-4} A_{1} \frac{\alpha_{1} \alpha_{2}}{\alpha_{2}+\frac{A_{1}}{A_{2}}\left(1-\alpha_{2}\right) \alpha_{1}} \frac{\gamma+1}{\gamma-1} \\
\quad \frac{P}{\sqrt{M T}}\left(T_{2}-T_{1}\right)
\end{gathered}
$$

$W:$ 伝熱量 Watt, $A_{1} A_{2}$ : 内外壁の面積 $\mathrm{cm}^{2}, P$ : ミクロン $\mathrm{Hg}, T_{1} T_{1} T_{2}$ : 夫々圧力計, 内外シリンダ 一壁の温度 ${ }^{\circ} \mathrm{K} \gamma: C_{p} / C_{v}$

図 1 の C.S. に扔いて真空度の変化とそれによる侵 入熱(残留ガスの分子伝導), 蒸発量の関係を表わせば 表 1 のようにりり真空度の低下により急に大きな熱伝 導量になる。図 1 の C.S. では液体 He を入れて真空度 は10-7torr 程度となりそれによる熱伝導は $10^{-4} \mathrm{~W}$ 位 と考えられる。ただし複雑な構造の C.S. や極端条件 下での使用に扔いて，気体のリークをなくすことは仲 タ困難であり,ことに低温部での各種シール,すなわち 電気的引出し線, 光学あるいは放射線の空等は C.S.

\begin{tabular}{|c|c|c|c|c|}
\hline \multirow[t]{2}{*}{$\mathrm{He}$} & $\mathrm{ac}$ & ommodation & coeficient & 0.5 \\
\hline & torr & $10^{-5}$ & $10^{-4}$ & $10^{-3}$ \\
\hline & watt & $7.85 \times 10^{-3}$ & $7.85 \times 10^{-2}$ & $7.85 \times 10^{-1}$ \\
\hline & $\mathrm{cc} / \mathrm{h}$ & 10 & 104 & 1040 \\
\hline
\end{tabular}
を製作する上の大きなポイントの一つである。シール

表 1 断熱壁の真空度と液体 He の蒸発量

$\mathrm{N}_{2}$ accommodation coeficient 1.0

$\begin{array}{lccc}\text { torr } & 10^{-5} & 10^{-4} & 10^{3} \\ \text { watt } & 1.35 \times 1 C^{-2} & 1.35 \times 10^{-1} & 1.35 \\ \mathrm{cc} / \mathrm{h} & 18 & 179 & 1790\end{array}$

上の $\mathrm{He}$ は真空中への $\mathrm{He}$ の洩れ

下の $\mathrm{N}_{2}$ は真空中への $\mathrm{N}_{2}$ の洩れの場合である が実際には洩れた $\mathrm{N}_{2}$ ガスは $\mathrm{He}$ 溜壁に吸着さ れる。 
として使用されるパツキンには，インジウム，充埪剤 入り tefron, SUS 製中空パツキン等が使用される。 その他溶接部やハーメチックシールからのリーク，コ 一ルドリーク等とアウトガス, 蒸気圧の大きなものや 吸着剤の存在する場合との区別等々リークハンティン グに多大の時間を費すのが現実である。 He の質量分 析型リークディテクターは非常に有用である。

さらに図 1 の.S. の例における液体 He の消費量 は，侵入熱を綜合すれば前出の計算により，
固体熱伝導によるもの
$0.11 \mathrm{~W}$

(但しパイプからの熱伝導は $1 / 2$ 以上 $2 / 3$ ガスの

顕熱により相殺されるとみれば） $0.08 \mathrm{~W}$ 輻射熱伝導によるもの

残留ガス伝導によるもの $0.2 \mathrm{~W}$ $10^{-4} \mathrm{~W}$ 合計
$0.28 \mathrm{~W}$

これ等が全部液体 He に対する気化熱となったとし て, He の気化熱は, $650 \mathrm{cal} / l$ から, 液体 $\mathrm{He}$ の蒸発 量は約 $370 \mathrm{cc} /$ hour となる。実測では $400 \mathrm{cc} /$ hour であった。外部流入熱に対する低温気化ガスの有する 顕熱によるキャンセル量, emissivityの研摩仕上度に よる微妙な相違, 空からの入射量, スペーサーの熱伝 達等仲々計算通りに法行ない。实構成材料は試料 台及び熱シールドが銅で亦るのを除く他SUS 27 を熱 処理したものであり, 初期冷却及び充墴には transferloss を加算して液体 He 約 $3.8 l$ を要した。これは 液体 $\mathrm{N}_{2}$ 亿て予泠後, 液体 $\mathrm{He}$ が満杯婂るまでであ り, $\mathrm{He}$ 溜はできるだけ熱容量を少く, 注入には初期 冷却を含めて約 30 分を要した。He 溜つみの初期冷却 の計算值は約 $130 \mathrm{cc}$ である。但し $\mathrm{He}$ 溜は容積約 $2 l$ で溜部 SUS 304, $550 \mathrm{~g}$, 試料台 Cu $200 \mathrm{~g}$, SUS 及び $\mathrm{Cu}$ の $80^{\circ} \mathrm{K}$ でのエンタルピーはそれぞれ 4 joules $/ \mathrm{g}$ 1-(5) 5 joules/g1-(6), He の気化熱 $0.65 \mathrm{cal} / \mathrm{cc}, \mathrm{He}$ ガスのエンタルピーは $80^{\circ} \mathrm{K}$ までで約 $12 \mathrm{cal} / \mathrm{cc}$ (液 体換算）であるがその半分が冷却に使用されたとして 約 $6 \mathrm{cal} / \mathrm{cc}$.

以上図 1 により断熱につき述べたが，C.S. におい て液化ガスの蒸発量が少いということは第一段階とし て大切ではあるがさらに試料の温度が所期の温度に下 がること, 温度制御がうまく行われること, 温度測定 が正しく行われること等が久かせない要件である。

\section{3 試料の温度の下限}

試料の温度は, 温度調節を行って上昇せしめること は割に容易であるが，用いた低温液化ガスの温度と同 じにすることは，その液化ガスに浸す以外はなかなか 困難である。普通使用液化ガスの温度に極く近い低い

Vol. 11 No. 3 (1976)
温度が必要な時には液溜に試料台をつけこれに試料を 取り付けその周囲に液溜から同温度の熱シールドをつ ける。液体 He の C.S. において，条件の上い時 5 6 ${ }^{\circ} \mathrm{K}$ 附近, 前項の接触部分の存在や光の入射等があれ ば $10^{\circ} \mathrm{K}$ 以下にするの以熟練を要する。また試料が薄 膜状のものであったり, 電気的に絶縁するため試料へ の熱が伝わり難い上らなときには He ガスの交換ガス を用いて泠却する場合もある。

\section{2 温度調節について}

C.S. では所要温度の調節にヒーターを使用する場 合が多いが，若し真空中で使用する時には，ヒーター 自身の温度だけが上昇しやすく, 許容電流は空気中で の $1 / 5 \sim 1 / 10$ 位に止めておいた方が無難であり, 最高 使用電圧,電源の区別を表示してあるのが普通である。 ヒーターの絶縁物としては，Tefron 同等品，フオル マール，ガラス繊維等の被覆線, シーズヒーター，ま たカ一ボン等の抵抗体や裸線も使用し, マイカ, 石英, サファイヤ, ベリリヤ磁器等を介在せしめる。ガス中 では問題はないが真空中では特に被加熱体との間に Apezon greece, GE 7031 等の接着剤を充填物とし て使用し，試料台との温度差を少くする場合もある。 シーズヒーターはその点最も効率よく，ヒーターとシ 一ズが耐熱性物質で絶縁されておう, 直接被加熱部に 巻きつけ且ろう接が可能である。ただしリード線との 接続には問題があり絶縁，out gas，過熱等に注意を 要するが，最近では同一のシーズ内に，リード線とヒ 一ター共々封入したものもある。温度調節の方法を大 別すれば，

1) ポンプ吸引による方法。図 2 に示す。

a ， b の例はポンプにて C. S. 内液化ガスを吸引し， 別試料部に低温の液またはガスを導き接触せしめ，そ の流量，圧力を調節することにより目的を達す。c 液化ガスの蒸気圧を真空ポンプにて調整してそれに接 たし試料の温度を調節する。主として液化ガスの温度 以下。

2) 液化ガスからの熱伝導による方法, 図 3 に示す。 a， c 液試料間の熱伝導度をかえて，b，試料を熱抵 抗を経て取付けたもの。これは液温から常温までの調 節は無理で，高い温度では液化ガスのロスが多い。

3）液化ガスとの間のガスの熱伝導によるもの, 図 4 。

2.3 温度計

C.S.に㧍いて試料の正確な温度を知るには，

1）その温度に応じた，感度のよい素子を選ぶ。 

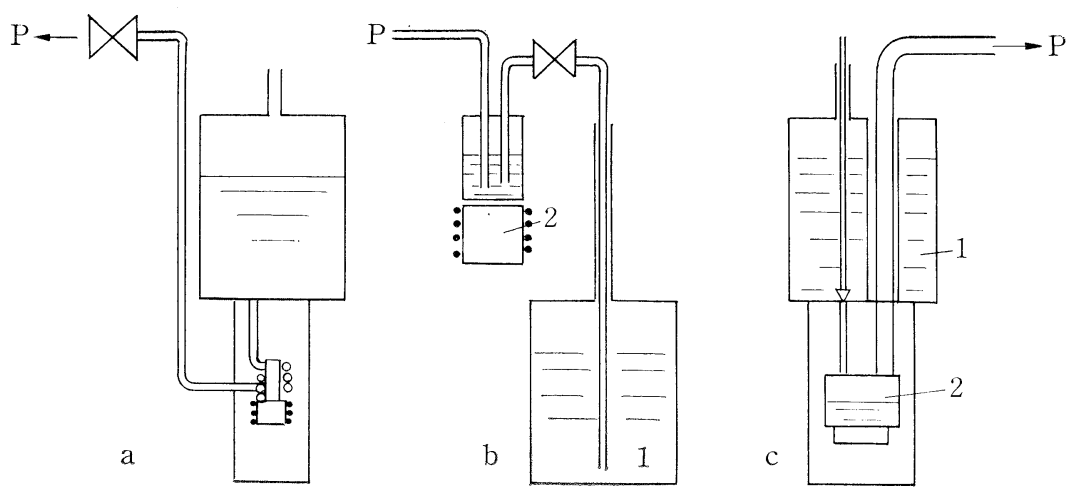

図 2

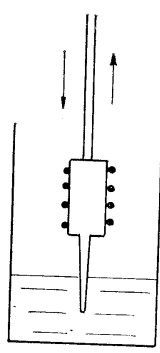

a

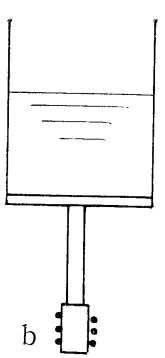

図 3
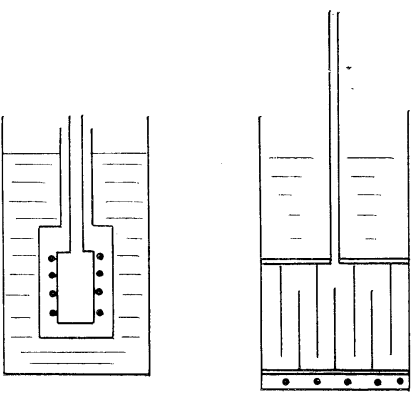

図 4

2) 試料と測定素子との温度差を少くする。

以上の 2 点が要点であるが，極低温用の数例をあげ れば,

○熱電対では，金合金が多く用いられ， $A u(\mathrm{Co})-\mathrm{Cu}, A n(\mathrm{Co})$-chromel 経年変化有, $A u$ $\left.(\mathrm{Fe})-\mathrm{Cu}^{4}\right)$ 低温での起電力大， $4^{\circ} \mathrm{K}$ で約 $12 \mu \mathrm{v} / \mathrm{deg}$, $10^{\circ} \mathrm{K}$ 附近にピークがあって常温では起電力少く, 零 接点を $0^{\circ} \mathrm{C}$ にすれば誤差が少い利点がある。 $A n(\mathrm{Fe})$-chromel ${ }^{4)} 20^{\circ} \mathrm{C}$ 以下の測定に適し, 液体 $\mathrm{N}_{2}$ 附近に零接点をとれば $10^{\circ} \mathrm{K}$ 以下の測定に好都合で亦
る。

○半導体素子では, $\mathrm{Ge}$ やカーボン抵抗 $(1 / 8 \sim 1 / 10 \mathrm{~W})$ が主で，感度よく極低温用二次温度計として有用であ るが，取り付方法による誤差が生じ易く，試料台に穴 をあけて Apiezon グリース，GE 7031等で接着する のが普通である。

○この他温度較正用として気体温度計, 液体 $\mathrm{He}$ 温度 以下には He の蒸気圧測定により, $4.2^{\circ} \mathrm{K}$ 附近にて 1 / $100 \sim 1 / 1000^{\circ}$ の測定が可能である。

\section{3. 各目的の C.S. の設計上の注意点}

電気関係の C.S. においては，リード線，導波管を 通じての熱流入が多く，導波管には洋白管を使用す る。外部引出線の絶縁部には八ーメチックシール等を 使用するが気化ガスや伝導により冷えない場所を選 ぶ。内部配線は熱絶縁及び低温における絶縁物破壊に 留意する。他線間の誘導，鉛，錫，半田等の超電導に 対する考慮。

磁気関係用では, 強磁場の狭い磁極間に入れる場合 が多く，その間に各々真空壁を介して液体 $\mathrm{N}_{2}$ 温度シ ールド及び液体 $\mathrm{He}$ 温度部分が必要にて, その極低温 壁内から常温壁まで片方で 実用的に最少 $4 \mathrm{~m} / \mathrm{m}$ 位が必 要であり，ナイロンの玉や糸をスペーサーとして使用 する。

光学用では空に対するシールことに低温部のシール が困難にて，低温用接着剤，インジウム，特殊加工

Tefron 相等品，中空金属パツキンのシールを使用す る。その他低温収縮による光軸の移動, 空材の選定が 大切。

機械的性質試験用としては，寒剂を初期冷却，伝導 に多く消費するものが多く, 従って温度の均一性, 機

低温工学 
1. 吸着室排気弁

2. サンプル室排気 弁

3. $\mathrm{He}^{4}$ 入 口

4. 測定用リード線 取出口

5. $\mathrm{He}^{4}$ 液面計入口

6. $\mathrm{He}^{3}$ 導 入 管

7. 排気 用管

8. 吸着筒断熱管

9. 制御七ーター

10. 高吸着性チャコ 一ル

11. 温度検出用カ一 ボン抵抗

12. $\mathrm{He}^{3}$ コンデンサー

13. $\mathrm{He}^{3}$ 液 溜

14. 温度検出用ゲル マニウム

15. サンプル台

16. 超電導コイル

17. ライトコーン

18. Heデュワー内径 $\phi 80$

19. ライトパイプ

（例 赤外検知器用

C.S.)

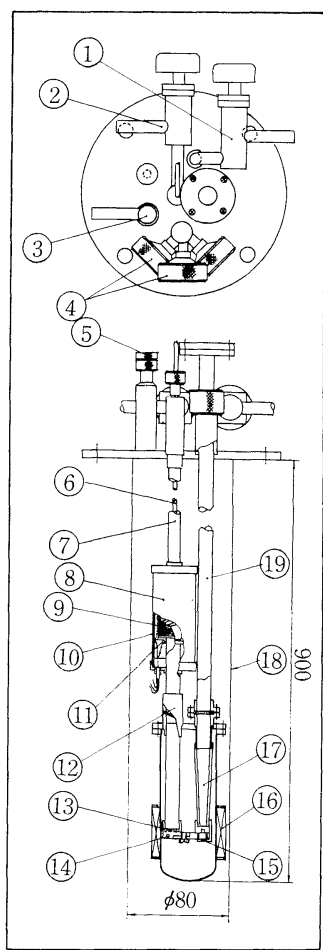

図 5

械的強度の保持等を考慮する。

液体 $\mathrm{He}$ 温度以下の C.S. 特に熱の侵入防止がその 到達温度, 能率を左右するものである。この1例とし て吸着型 $\mathrm{He}^{3}$ C.S. を説明する。これは遠赤外検出用 のものである。図 5 はその要部を示すもので, 活性炭 の入った吸着部, $\mathrm{He}^{3}$ のコンデンサー，検出器の保持 台に連結された液体 $\mathrm{He}^{3}$ 溜, ライトパイプ及び light cone, フィルターを備えた遠赤外線導入系，低温保持 用各ガス供給管や真空用排気管及び電気的リード線端 子をつけた上部フランジ等からなっている。これ等は 上部フランジを除いて減圧した液体 $\mathrm{He}^{4}$ の中に浸して あり，従ってさらにその外側には真空壁をへだてて， 液体 $\mathrm{N}_{2}$ シールドがあるわけである。

吸着室の大きさは $23 \mathrm{~cm}^{3}$ でその中に $9 \mathrm{~g}$ のチヤー コール及びヒーターを巻いた筒が吸着室の壁に直接触 れないよう内蔵されており，その下部のステンレスパ イプには銅製のラジェーションシールド及びコンデン サーがありステンレス管壁と共に何れも減圧液体 $\mathrm{He}^{4}$ 温度にて $\mathrm{He}^{3}$ のコンデンサーとして動作する。液体 $\mathrm{He}^{3}$ 溜は銅製にて，コンデンサーに長さ $80 \mathrm{~m} / \mathrm{m}$ ，径 12 mm, 厚み 0.3 m $m$ のステンレス管にて連結している。ま
たこの $\mathrm{He}^{3}$ 溜は検出器台を兼ねており重さは $30 \mathrm{~g} に$ て銅製である。図の右の方は遠赤外導入系で下方に気 密にしたサファイヤ空及び冷却フィルターを持つライ トパイプ，その下部に銅製 light cone が検出器台か ら 2 m/mはなれた所束できている。その外部には断熱用 真空シールドがありフランジにインジウムシールを施 してかつその外側に超電導マグネットを備えている。 温度計, 検出素子のリード線には $0.08 \mathrm{~m} / \mathrm{m}$ のマンガニ ン線が使用され heat trap としてステンレスパイプに GE 7031 にて接着してあり，真空壁から $\mathrm{He}^{4}$ 溜への 引出し部には細いパイプを通して stycast にて封じ る。温度計素子としては, $A u(\mathrm{Fe})$-chromel, カーボ ン抵抗，ゲルマニユームが使用される。

その働きは吸着室に $\mathrm{He}^{3} カ ゙$ ス入れると低温の活性 炭は $\mathrm{He}^{3}$ を吸着する。上部のバルブを閉じ，ヒーター にて活性炭を加熱すればガスは脱着してコンデンサー にて液化し受器に溜まる。十分液化してヒーターの加 熱を止めると活性炭は復び吸着を始め溜内の液化 $\mathrm{He}^{3}$ は気化し温度は下降する。 $\mathrm{He}^{3}$ 溜の到達温度は同部一 の侵入熱と活性炭の温度及び活性炭の性能（活性度） とによる。結果として

減圧 $\mathrm{He}^{4}$ の温度 $2^{\circ} \rightarrow 1.5^{\circ} \mathrm{K}$

活性炭の温度 吸着時 $9^{\circ} \mathrm{K}$ 以下 (脱着時 $40^{\circ} \mathrm{K}$ ) 大力熱量 (検出器への入力も含めて) 約 $100 \mu \mathrm{W}$ 亡 して $\mathrm{H}^{3}$ 溜の温度（検出器の温度） $0.40^{\circ} \mathrm{K}$
同上温度への到達時間
3 分 冷却開始より
同上温度の持続時間
5-7 時間
$\mathrm{He}^{3}$ ガス量 $1 l / \mathrm{STP}$

C.S. の例は枚挙にいとまなく，今後も低温研究の 資として，その必要性と利用度はさらに広範にわたっ てくるものと思わ机る。最後に本稿の赤外線検出用 C.S. では阪大山本氏のレポート(5)にる特殊な例を 挙げたが，紙面をかりて同氏に感謝の意を表します。

\section{参考文 献}

1) NBS properties of materials at low temparature. part 2 thermalconductivity of Solids.

1-(1) 3,301 1-(2) 3,501 1-(3) $3,112-1$ 1-(4) $3,112-2$ part 3 specific heat and enthalpy of cryogenic solids 1 - (5) $4,112-1$ 1-(6) 4, 181

2) 山本純也：低温工学発表会15回低温構造材料の 赤外分光反射率 1975

3) R. B.Scott : Cryogenic engineering. p. 153

4) 高野安正, 阿部仁志, 信貴豊一郎, 松原洋一, 柳井正誼, $\mathrm{Au}(\mathrm{Fe})$ 合金を用いた極低温熱電対： 低温工学 Vol. 9 No.2 1974

5) J.Yamamoto "A $\mathrm{He}^{3}$ Cryostat using a charcoal adsorption pump for a far-infrared detector," : J. J. A.P. Vol.14 No.11 1975

Vol. 11 No. 3 (1976) 